\title{
The concept of smart city and the perceptions of urban inhabitants: a case study from Žilina, Slovakia
}

\author{
Tatiana ČOREJOVÁ ${ }^{1}$, ERIKa HAL'AMOVÁ ${ }^{1}$, RAdovan MADLEŇÁK ${ }^{1}$ and \\ GYörgy IvÁN NESZMÉLYI²
}

\begin{abstract}
The smart city concept is a comprehensive approach to the functioning of the urban region. It concerns various areas of life such as culture, infrastructure, environment, energy, and social services. Public perceptions of the smart city concept are not commonly addressed. The aim of this paper is to examine perceptions of the smart city concept among inhabitants, doing so through a case study focusing on the city of Žilina in Slovakia. The methodology that the researchers applied includes primary research and surveys as well as secondary research. Based on the analysis of the environment and the results of the survey, opportunities for the development of a 'Smart City Žilina' concept are identified. There is a growing interest in green solutions among the inhabitants of Žilina. A significant number of respondents indicated their support for intelligent waste collection and renewable energy sources. And they were also supportive of green roofs. The update of the strategy must consider a number of steps in waste management, from collection to transport, with a view to the overall recovery of the waste generated. As part of the smart city concept and projects, the public administration and the municipality must communicate effectively with the public. This will require specific approaches and tactical decisions for optimal success.
\end{abstract}

Keywords: Smart City concept, case study, perception, inhabitants, public administration, communication

Received March 2021, accepted May 2021

\section{Introduction}

The issue of smart cities has been addressed in the last decade in many forums. The concept is gaining more and more importance and comes to the fore not only in terms of scientific research itself, but also in terms of the application of its results. This trend follows the growing urbanization and the increasing proportion of the population living and working in cities. As the urban population share increases, many of the challenges facing urban management can be identified. Smart city has many dimensions and touches on the need for a more interactive and faster city administration and safer public spaces. The concept of smart city mainly affects the quality of life of the city's inhabitants, and the criteria by which it can be measured include: quality of the working environment, possibilities to buy goods and services, leisure time, sense of social security, personal development, physical quality of the environment, economic development and housing and the possibility of participating in public life.

The smart city concept is therefore a comprehensive approach to the functioning of the urban region, which extends to different areas of life such as culture, infrastructure, environment, energy, social services and more. Each of

\footnotetext{
${ }^{1}$ University of Zilina, Univerzitna 8215/1, 01026 Zilina, Slovakia. E-mails: tatiana.corejova@fpedas.uniza.sk, erikahalamova94@gmail.com, radovan.madlenak@fpedas.uniza.sk

${ }^{2}$ Budapest Business School, University of Applied Sciences, 1055 Budapest, Markó u. 29-31.

E-mail: neszmelyi.gyorgy@uni-bge.hu (corresponding editor)
} 
these areas pursues several objectives which are interrelated and jointly create a system based on the principles of sustainable development. Public administration, the private sector and civil society enter this system, without which the set objectives would not be met.

EU cohesion policy for the period 2021-2027 also emphasizes the strategic goals of a smarter Europe, green solutions, a connected and social Europe that is closer to the citizen and supports local development strategies and sustainable urban development (New Cohesion Policy 2018). It emphasizes the citizen and his / her environment, which will improve his / her life, living conditions and sustainability. Therefore, it is also important to examine how citizens perceive individual smarter, green, sustainable and renewable solutions that are prerequisites for the fulfilment of the strategic objectives of EU cohesion policy. Public perceptions of the concept of smart city have rarely been investigated by researchers. This paper focuses on the perceptions of the smart city concept among inhabitants of Žilina in Slovakia. Applying the principles of smart city in a specific location evokes several research questions:

- Do the inhabitants of the city know the concept of smart city and its connection with other functionalities of the city and its life?

- What do citizens consider crucial for improving living and business conditions in the city?

- How are the benefits of projects implemented under the concept of smart city and what is important in the concept from the perspective of different segments of the population and visitors to the city?

The paper reports on research results of a case study within the city, which has about 80,000 inhabitants, but which represents, in a broader sense, the centre of a region with about 600,000 inhabitants, including attractive destinations for domestic and foreign tourism, are presented in the rest of the paper. Subsequently, recommendations concerning the public communication of the smart city concept are given. The recommendations may be of benefit to the administration of the city or they may facilitate the operation of individual smart components of the infrastructure.

\section{Theoretical background}

In urban development, a modest rise of creativity started during the 1980s. The mid-1990s saw the emergence of the creative city concept. At the beginning of the 2000s, the creative economy and the cult of creativity rapidly spread around the globalizing world. After the crisis of 2008-2009 the smart city concept came to the focus of attention (EGEDY, T. 2017). Since then, globalization has been reshaping national economies by extending market conditions and competition around the world. A profound transformation in the nature and conditions of competition resulted in a policy of deregulation (ERDEINÉ KÉSMÁRKI-GALLY, Sz. et al. 2015), therefore, regional and local initiatives have been gaining increasing impetus and importance worldwide. Of these initiatives, environmentally friendly, sustainable and citizen-friendly solutions aimed at modernizing of urban areas, combined with the implementation of state-of-the-art technologies ('smart cities'), need to be identified as a relatively new phenomenon.

According to the Smart City Dictionary, the smart city concept represents an urban development vision that integrates information and communication technology (ICT) and the Internet of things (IoT) technology in a secure way to manage a city's assets. According to the Business Dictionary, smart city is a developed urban area that creates sustainable economic development and a high quality of life by excelling in multiple key areas; economy, mobility, environment, people, living and government. It is possible to excel in these key areas through strong human capital, social capital or information and communication technology infrastructure. Of the many options available, the British government's inspirational approach can be considered (Department Business, 2013). It states that the concept of 'smart city' is dynamic and that there is no absolute definition of a city that is smart. The concept is endless and is rather a process or a series of steps that make cities more habitable and resilient and, thus, able to respond more quickly to new challenges. 
A detailed analysis of literary sources in relation to smart urban governance is given by Meijer, A. and Rodríguez Bolívar, M.P. (2015), who emphasize the multidisciplinary nature of the subject of smart city. Definitions of smart cities usually focus on three key topics, namely technology, people and governance in the city and subsequently on their interactions (see also smart cities dictionary and definition). It has also been claimed that the key elements of national and regional e-tourism strategies in the Carpathian Basin need to be analysed in the broader framework of ICT strategies for development (DÁvid, L. and Szúcs, Cs. 2009), while ZimáNYI, K. et al. (2014) discussed the new forms in the online sales in commerce and tourism.

According to the Web of Science and Scopus databases and according to the subject of the solution, literary sources on smart city are predominantly assigned to technological areas - electrical engineering, engineering, ICT and their applications. The smart city definition by JIA, Q. and $\mathrm{XU}_{\mathrm{U}}, \mathrm{C}$. (2021) is connected with the combination of advanced sensors to manage the city's assets and the information technology virtually. MossBerger, K. and TolberG, C.J. (2021) also state that "over the past decade, the vision of smart cities filled with technological innovation and digitally engaged citizens has been pursued around the globe, but not all city residents have a chance to participate in or benefit from these innovations". McQuire, S. (2021) argues for the need to decouple thinking regarding the potential of urban digital infrastructure form the narrow and often techno-centric discourse of 'smart cityism'. Such a decoupling will require continued experimentation with both practical models and conceptual frameworks but will offer the best opportunity for the ongoing digitization of cities to deliver on claims of 'empowering' urban inhabitants.

Regarding geography, urban studies and urban and regional planning, about 10 per cent of all the records fall in te field in both databases. The increase in smart city publications in the last decade has been enormous. It represented up to 98 per cent of the total number of publications on the topic of smart city. Overall, Smart City is a city where the traditional system of urban infrastructure and services is enhanced by modern digital and telecommunications technologies.

One may ask why only in cities and not in rural areas? Smart villages are a rarity, particularly in Central and Eastern Europe. The answer may also be simple, as the gap between living conditions in urban and rural areas is still too large, despite the EU-funded cohesion projects. A survey in the South Moravian part of Czechia showed that almost a fourth of municipalities support commercial trade and services, mainly through subsidies or lowered rent. Even simplifying red tape or providing tax relief would help to support civic amenities, but another key development would be retaining young and educated people in municipalities where they will live and work (Šllhan, Z. and Kunc, J. 2020). An important question was raised in relation to Hungary (but probably it relates to the entire CEE region), namely whether the digital divide follows the industrial divide in the economic space or not (KIss, É. and Nedelka, E. 2020).

Many definitions consider smart city as well as intelligent city as a one-way approach to communication, and therefore decision-making on individual projects that make up smart city is not an optimal choice (Rechnitzer, J. et al. 2019). It should not be a top-down or a bottom-up approach, but one based on cooperation, with communication in all directions (DADO, M., ZAHRADNIK, J. et al. 2007). It is not enough for people to have access to information; a further requirement is for information to be created.

Each smart city is characterized in particular by the following features:

- Smart economy - innovation, entrepreneurship, economic image and brands, productivity, labour market flexibility, international attractiveness.

- Smart mobility - local accessibility, national accessibility, availability of information technologies and infrastructure, sustainability of the transport system. 
- Smart conditions for life - cultural facilities, health conditions, individual safety, quality housing, school facilities, tourist attractiveness, economic prosperity.

- Smart governance or administration, management systems - participation in public life, public and social services, transparent administration.

- Smart environment - environmental conditions, air quality (no pollution), ecological thinking, sustainable use of resources.

- Smart citizen - level of acquired qualification, lifelong learning, ethnic plurality, free will (http://www.smart-cities.eu).

It is necessary to mention the six-axes model of Cohen, B. (2012), who identified smart cities by six main dimensions (Figure 1). The model is frequently cited in the international literature. Examples include SoE, R.M. (2017), who reflected on examples in Estonia and Finland, and Dово et al. who developed a methodological recommendation based upon positive examples in the world including Helsinki, Copenhagen, Ljubljana, London, Amsterdam and Vienna (Dовоs, K. et al. 2015).

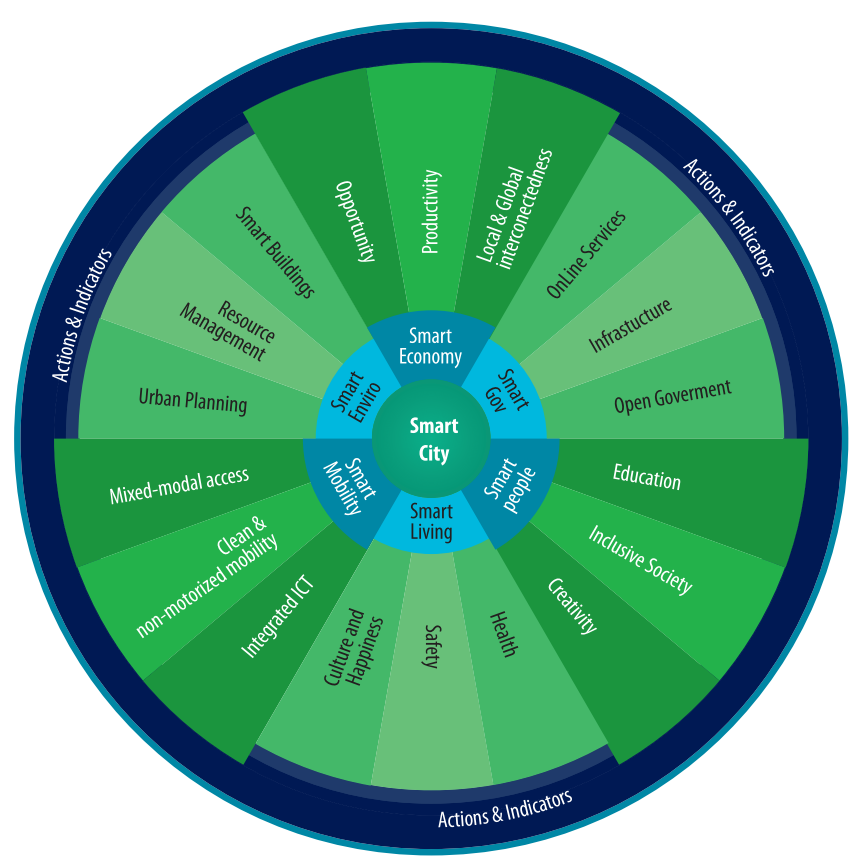

The axes of CoHen's model are: smart economy - smart mobility - smart environment - smart people - smart living - and smart governance. These six axes formulate links with traditional regional and neoclassical theories of urban growth and development.

In addition to these cities, there are many smart city projects or smart city initiatives in the world, especially in developed countries. In South Korea, the example of Songdo city can be mentioned, a new settlement which was established in the early 2000s, and the smart city project was launched during the tenure of former president Lee Myung-bak (2008-2013), who supported the idea of environmentally sound and sustainable urban development with low carbon-dioxide emissions. The costs of the project amounted to around 40 billion USD, with several multinational companies and local authorities working together in a PPP (private public partnership). The aim was to develop a sustainable settlement and a viable international economic centre (CzIRJÁK, R. 2016).

In Hungary a number of towns and cities have implemented smart citysound development projects. However, some of these projects have been placed in this category in view of the advantageous funding possibilities, while in other cases the objectives were more complex and well elaborated, especially in the field of public utility development (То́тн, G. et al. 2013). The settlement evaluation system in Hungary comprises six major criteria - smart mobility - smart environment - smart people - smart living - smart governance - smart economy. These criteria are further divided into sub-categories and

Fig. 1. The smart city wheel by Cohen, B. (2012) 
also relate to the respective Cohen-indicators (Doвоs, K. et al. 2015)

The smart city uses new technologies, including information and communication technologies (ICT), to increase the quality and performance of urban services, reduce costs and resource consumption, and involve its citizens more effectively and actively in city life (see VAculík, J. and TengLeR, J. 2012). Sustainable development in particular is the basis. This development of human society is one that reconciles economic and social progress with the full preservation of the environment (Madudova, E. and Dávid, A. 2019). A major goal of sustainable development is to preserve the environment for future generations. It is based on the social, economic and environmental pillar (Kalašová, A. 2012).

The introduction of the concept of a smart city brings several benefits. Among the benefits of smart cities, we can include:

- Increased level of functionality of the city: employment opportunities, access to basic aspects of prosperity - to infrastructure services such as interconnection and connectivity; reliable, sustainable and low-cost energy sources; adequate training opportunities; affordable forms of housing and efficient transport.

- Sustainability: is a method by which resources are not depleted or permanently destroyed. Sustainability is not only about the environment, but also about the economy. Smart cities make efficient use of natural resources, economic resources and human capital to create their urban infrastructure that delivers the highest possible outputs and costs as few inputs as possible.

- Raising inhabitants' living standards: access to a comfortable, healthy, clean, safe and active lifestyle, which includes several aspects such as cheap energy sources, convenient public transport, quality education, faster public services, clean water and air quality, low rates crime and access to various entertainment and cultural opportunities (Smart City 2014).

Important features of the smart city are, therefore, a cooperation economy, a shared economy, a green economy and a circular economy (MatúšKová, M. and MadLEŇÁKová, L. 2016). These represent changes in the social paradigm of the position of people in society in the $21^{\text {st }}$ century, who do not need to own items of daily consumption and are able to use common products thanks to various communication tools (Turská, S. and Madlenáková, L. 2019). People or organizations share the resources at their disposal that they do not make full use of (e.g. cars, infrastructure). They collaborate and reuse in the context of sustainability and environmental protection (Woetzel, J. et al. 2018). This concept embraces four basic elements:

- transport, e.g. sharing of vehicles, bicycles, public transport;

- energy, e.g. concepts of shared electricity generation;

- public space, e.g. sharing investments and activities in joint projects;

- social, e.g. sharing of living space, catering, etc.

We can say that the concept of a smart city and a sharing, collaborative or circular economy lead to the decentralization of political and economic power, to economy and to a conscious behaviour towards the environment in which we live.

Each city is unique and faces its own problems that it must solve. For this reason, it is questionable, whether one can assess which city or which country is currently the smartest. However, there are several rankings that try to answer this question. The best known are the Cities in Motion Index, the IMD Smart City Index and the European Smart City Model. The Cities in Motion Index evaluates cities in terms of ten areas. The IMD Smart City Index includes citizens' perceptions among the evaluation criteria of smart city levels. Citizens' perceptions, on the other hand, are balanced by economic and technological aspects.

The European Smart City Model (European Smart Cities 3.0 Home) provides an integrated approach to defining the profile and comparing medium-sized European cities and can be seen as a tool for effective learning in the field of processes related to urban innova- 
tion in specific areas of urban development. Cities according to the model are divided into two groups according to the number of inhabitants. In the first group there are cities with a population of $100,000-500,000$, in the second group 300,000-1,000,000.

Within Slovakia, however, only two cities currently belong to these categories, namely Bratislava, the capital of Slovakia, and Košice. Other regionally important cities have less than 100,000 inhabitants. Based on research by GifFinger, R. and HaindLMAier, G. (2010), eight Slovak cities with a population of 50,000-100,000 were evaluated using a smart city index that includes 6 mutually relativity independent areas and a total of 31 relevant factors. None of these cities were the best in all areas. Overall, the best rankings in 2020 were achieved by Banská Bystrica, Nitra and Žilina (Table 1). Other cities have lagged significantly behind. Based on these values, we decided to pay more attention to the city of Žilina in terms of citizens' perceptions of the smart city concept.

Smart cities are, thus, a developing segment of the market with innovative solutions, which, however, are not an end in themselves, but a means to increase the quality of life in cities and to improve the business environment.

\section{Aims and methodology}

The aim of the paper is to examine perceptions of the smart city concept among the in- habitants of the city Žilina in Slovakia. The research methodology was based on an analysis of secondary sources from the point of view of the concept of smart city according to Cohen, B. (2014) and the Smart City Index (2020) and on primary research conducted through a questionnaire survey. The survey of perceptions of the smart city concept among inhabitants of the city was focused on finding out to what extent the inhabitants have knowledge of the concept, what they consider to be crucial areas that need to be solved within the city, and how they evaluate already implemented projects within the concept. The survey was conducted using a structured questionnaire. A pre-test was also carried out with five respondents. Based on that the method was slightly modified, and during the selection of respondents the concept of smart city was briefly introduced. The adjustment resulted from the fact that 4 out of 5 randomly addressed respondents did not know the importance of the smart city concept or confused it with a hard disk monitoring system that detects and sends reports on various reliability indicators in an effort to predict failures. The indicators must meet the criteria of S.M.A.R.T. - and must be Specific, Measurable, Accessible, Realistic and Timely.

The selection of respondents in the survey was random and included the public/residents living and/or working or studying in the city. Data collection and processing took place in March-April 2020, using a combination of personal (March 2020) and online (April 2020 due to anti-pandemic measures)

Table 1. Ranking of Slovak cities with 50,000-100,000 inhabitants according to smart city index in 2020

\begin{tabular}{l|c|c|c|c|c|c|c|c}
\hline \multirow{2}{*}{\multicolumn{1}{c|}{ City }} & \multirow{2}{*}{ Population } & \multirow{2}{*}{ Position } & \multicolumn{5}{c}{ Smart } \\
\cline { 4 - 9 } & & & economy & people & governance & mobility & environment & living \\
\hline Banská Bystrica & 78,327 & 1 & 1 & 1 & 4 & 3 & 3 & 4 \\
Nitra & 76,655 & 2 & 4 & 2 & 1 & 2 & 1 & 6 \\
Žilina & 80,810 & 3 & 2 & 3 & 2 & 4 & 6 & 2 \\
Poprad & 51,304 & 4 & 7 & 8 & 7 & 1 & 7 & 1 \\
Trnava & 65,207 & 5 & 3 & 5 & 6 & 5 & 4 & 8 \\
Trenčín & 55,333 & 6 & 8 & 7 & 3 & 6 & 2 & 7 \\
Martin & 54,618 & 7 & 6 & 4 & 8 & 8 & 5 & 3 \\
Prešov & 88,680 & 8 & 5 & 6 & 5 & 7 & 8 & 5 \\
\hline
\end{tabular}

Source: by Smart City Index, 2020. 
inquiries. The questionnaire consisted of identification and merit questions. The survey examined the frequency of individual answers within closed questions. In selected questions, a multiple answer was possible, as well as an assessment of the significance of the elements. The unipolar Lickert scale (0-4) was used to assess significance. The formulation of meritorious questions followed in-depth interviews with employees of the city of Zilina, analysis of secondary sources and concerned individual areas of the city's strategy from the point of view of the smart city concept.

The methods used in this paper are clearly based on the application of analytical, synthetic and comparative methods that also represent recommended methods in the application of diagnostics and subsequently therapeutic methods in the process of the investigation of inhabitants' perceptions and expectations regarding the smart city concept and projects related to the smart city concept.

When determining the number of respondents in the survey, we based it on the current number of inhabitants living in the city of Žilina (in 2020 it is 80,810). We also set the reliability of the estimate at 95 per cent, with the maximum allowable error range being set at 9 per cent and the variability of the base set at 0.5 . The total minimum number of respondents was set at 118 (Halamova, E. 2020).

In terms of age structure, the largest group consisted of respondents aged 20 to 30 years (63 respondents, which is almost $54 \%$ of the total). The stated composition of the respondents also reflected the fact that this age group uses online connections more intensively due to the electronic form of the questionnaire. In terms of educational attainment, most respondents had a secondary education (60\% of the total number), respondents with a university degree $(30 \%)$ and respondents with a primary education $(10 \%)$. The largest group, depending on gender, age and education, consisted of men aged 20 to 30 years with secondary education (19\%). As part of the questionnaire survey, we were interested in the form of the respondent's stay or residence in the city of Žilina. As Žilina is a regional city and is considered the 'metropolis' of northern Slovakia, many citizens come to the city for various reasons. Of the total number, respondents with permanent residence in the city accounted for 62 per cent, over 26 per cent of them worked or studied in the city, and 10 per cent visited Žilina temporarily. The other respondents were either staying temporarily in the city or had come to the city to work or study.

\section{Results of the case study}

A major strategic goal of the city is to create the conditions for sustainable development. In other words, Žilina wants to be a city in which there are permanent conditions for the continuous optimization of the living conditions of both inhabitants and visitors. This aim is to be fulfilled in line with the natural and historical conditions of the city environment (www.zilina.sk ). The city of Žilina, as the centre of the wider region, also directly cooperates with the Žilina self-government region (further ŽSK) and builds on several of its documents (ŽSK, 2015, 2016). In individual projects, it cooperates with other entities, including businesses, the University of Žilina and non-governmental organisations (NGOs) (Strelcova, I. 2016; Jesenko, M. 2017; SAD Žilina 2019).

Competences transferred from the central level of the state to the level of the city of Žilina under Slovak legislation, are in the following areas: transport and communications, social services, waste management, culture and tourism, primary education, local taxes, applications and issuing various permits for residents and institutions operating in the city, as well as the city's own management and emergency management. If we build on the theoretical definition of the concept of smart city according to CoHEN, B. (2012) as well as by Smart City Index (2020), it is possible to identify certain positive solutions according to individual smart areas and based on an analysis of secondary sources of the city. An advantage for the city is the presence of 
the university and several research institutes, which have long been dealing with transport issues, new technologies in transport, ICT, engineering, construction and energy. Selected municipal institutions are actively involved in several projects run by these institutions. At the same time, the university actively contributes to the elaboration of the city's spatial plan and to the shaping of transport policy. Of course, the city's zoning plan itself, as part of its updates, is influenced by new elements associated with smart solutions.

Smart mobility includes smart transport and so we identified technological solutions associated with smart public transport and traffic management (STRELCOVA, I. 2016; SAD Žilina 2019). From the perspective of public transport, the essence of smart traffic management in Zilina is important. Active communication board units are applied in vehicles with stop road traffic signal controller, which controls the crossing intersections to the current position. The system along with other traffic information is integrated into the software platform. This may be the mobile app Smart Zilina and the web smart.zilina.sk benefit residents and dispatchers transport company. Other smart mobility solutions include:

- a bike-sharing;

- an intelligent system for controlling access to the pedestrian zone, which contributes to a reduction of the number of vehicles in the pedestrian zone. The regulation of parking in city neighbourhoods is aimed at streamlining the use of parking spaces and at reducing the number of surplus vehicles.

Transport in Žilina in the context of smart mobility would be focused in future on complex regulation (e.g. the regulation of individual vehicles, public, bicycle and pedestrian transport, including the solution of static transport). The aim is to shift passengers from individual car transport to sustainable modes of transport.

Within the smart environment as a part of the smart city concept two projects, Airtitia and Solez, are being addressed. The city of Žilina is located in a basin with unfavourable geographical conditions in terms of the dis- persion of emissions in the air. Reducing the burden of emissions in the urban environment has traditionally been among the priorities of the city of Žilina. Within the framework of Airtritia, measures have been taken to monitor air quality and to develop an action plan addressing critical levels of air pollution in the city. The project Solez enabled the city to develop an action plan for low-carbon mobility, introducing low-carbon measures, alternative means of transport and low-emission zones.

Smart conditions for life are connected with the smart energy infrastructure based on intelligent network elements, enabling the use of renewable forms of energy and regulating the behaviour of both producers and consumers. The growing number of cars on the road puts pressure on the use of cleaner vehicles, especially electric cars, and hinders shared mobility opportunities. The city also created an initial scheme for promoting health and improving the quality of life of citizens and visitors, with support being given to initiatives relating to human capital, education, social inclusion and citizens' cooperation. It finances its projects mainly using international grants, EU funds, the resources of the KIA Motors Slovakia Foundation and its own resources.

Efforts to improve the effective management of resources and to ensure adequate responses to the interests of citizens, social organizations, companies and administrations, led the city government to seek membership of the Smart Cities Club (membership was achieved in September 2019).

It can be stated that separate strategies for individual areas according to the concept of smart city have not yet been formulated at the city level. However, individual projects gradually contribute to the fulfilment of the concept. The projects touch on key areas in terms of the city - mobility and the environment. In these two areas the city of Žilina has a low ranking on the smart city index (see Table 1). In the area of smart people, the city of Žilina does not have all the competencies and needs to cooperate with the Žilina self-governing region (ŽSK) and the university, which operates in the city and has a much broader scope. 
Similarly, in the smart economy, the city focuses on its own management and the exercise of its competencies in the field of taxes and fees, which determine the characteristics of the business environment in the city.

The findings of the primary research (Hal'amova, E. 2020) are presented in the following sections of the paper. In terms of their perceptions of the smart city concept, respondents consider it primarily as a technological concept associated with the use of new modern technologies and especially ICT. When choosing the answers, they had three options, namely that they perceive the concept as a change in society, a change in the solutions used and the implementation of new technologies. 63 per cent of respondents chose one of these options. 70 per cent of respondents perceive the term 'smart city' to be associated with the use of modern technologies, while less than 10 per cent associate it with a 'change in society' (Figure 2).

In addition to knowledge of the concept of smart city and its connection with various changes, respondents commented on their knowledge of the city's investment in the concept. Respondents with a university degree are expected to have a higher level of knowledge. Also, some of the respondents' job descriptions may distort the findings, as some respondents work in the state and public administration. Our assumptions concerning respondents' job classifications were confirmed. Respondents with secondary education working in the state and public administration had the most knowledge about the city's investments in smart city. We found that up to 43 per cent of respondents did not know about investing in smart city, while 30 per cent of respondents think that the city does not invest in smart city. Based on the findings, it can be stated that most of the respondents do not have knowledge about investing in smart city, which reflects insufficient communication between the city and citizens. Only 29 respondents have knowledge about investments.

The perception of smart city as the use of new technologies proved to be essential, what the citizens themselves do not directly connect with changes in the city and society itself. Subsequently, the attention of the respondents was focused on the question of what they consider to be decisive or most important in terms of the future development of the city.

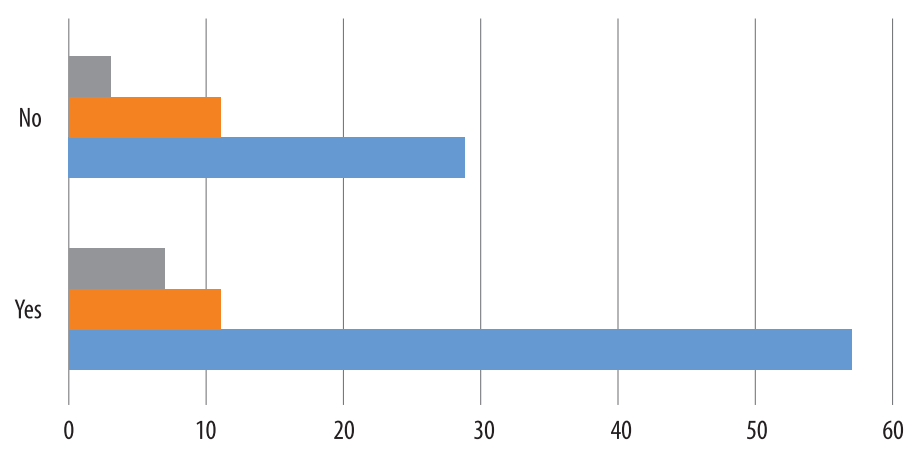

\begin{tabular}{|l|c|c|}
\cline { 2 - 3 } \multicolumn{1}{c|}{} & Yes & No \\
\hline Change in society & 7 & 3 \\
\hline Change in approach to solution & 11 & 11 \\
\hline New technologies & 57 & 29 \\
\hline
\end{tabular}

Fig. 2. Knowledge of the term Smart City and its connection with selected items. Source: Havamova, E. 2020. 
More than 26 per cent of respondents consider intelligent waste collection to be the most important area of the development. The second most important area of development according to respondents is the use of renewable energy sources (25\% of respondents). Respondents consider the management of public lighting to be the least important area (12\% of respondents). From a gender perspective, men consider smart waste collection and support for the use of renewable energy sources to be the most important areas for development, and only 8 men consider support for the construction of green roofs the least important area. Women also consider intelligent waste collection to be the most important; according to them the use of renewable energy sources is also important, and they also consider the construction of green roofs to be an important area. It is interesting in terms of stereotypes in Slovak society that women do not consider public lighting management to be an important area. It should also be noted that, in the 20-30 age group for both men and women, the promotion of renewables in particular plays an important role. For respondents over the age of 50, the results are different, with men promoting intelligent waste collection and support for renewables and women promoting green roofs. The comprehensive results obtained from the survey are shown in Figure 3.

This was followed by a survey of respondents' perceptions of individual sub-projects that were and are being implemented within the city and can be assigned to individual areas of the smart city concept. These projects in terms of secondary research include a bike-sharing system, a smart system for monitoring the entrance to the pedestrian zone, a smart public transport system connected with 'green' preferences at crossroads, the monitoring of air quality, e-services for communication between citizens and municipalities, and the establishment of a contact point for municipality services. The city of Zilina has implemented several projects within the smart city framework. The 'bike-sharing'

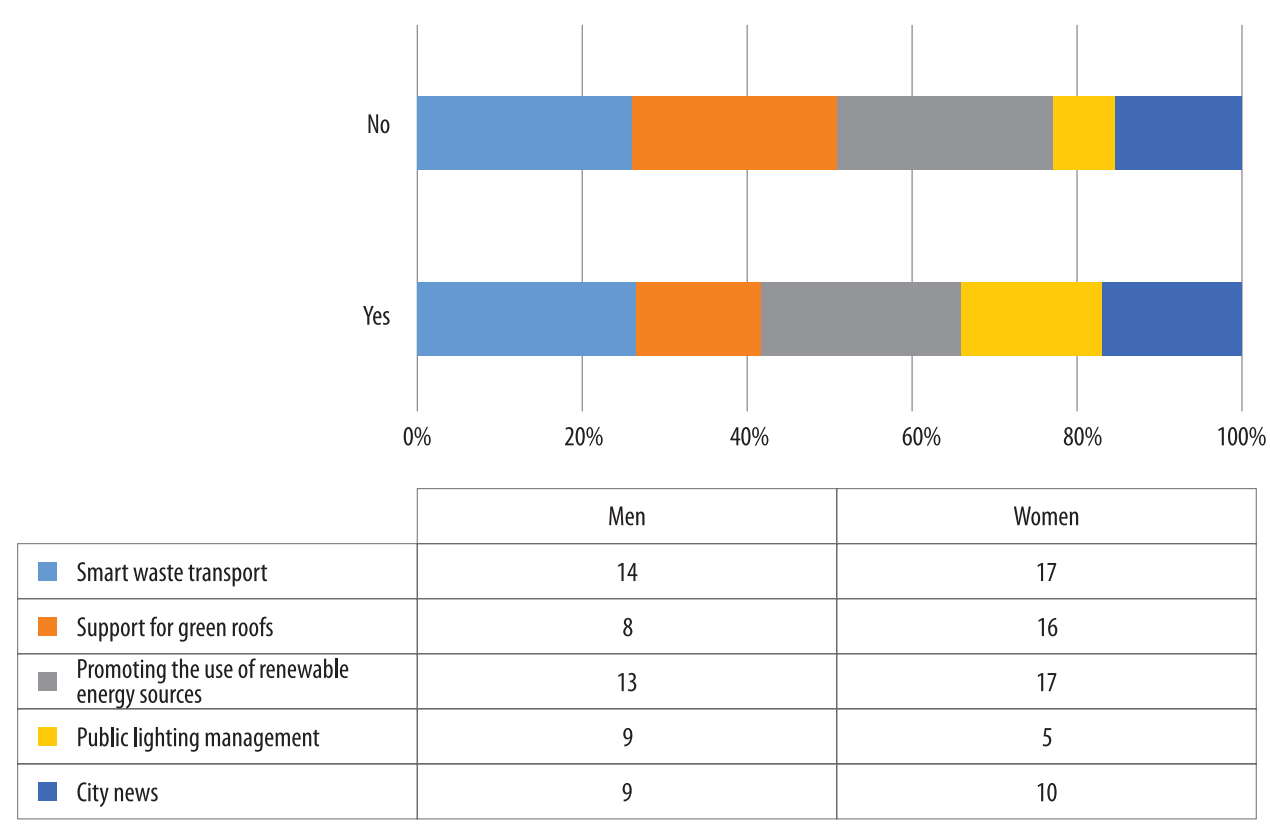

Fig. 3. Potential areas of the Smart City concept in Žilina by gender. Source: HaL'amova, E. 2020. 
system BIKEKIA is rated as the best project (Figure 4). As many as 38 per cent of respondents rate it as the best, while the project for electronic communication between the citizen and the office came in second place. Less than 6 per cent of respondents consider a smart system for regulating pedestrian entrances to be the best project.

In terms of the nature of respondents' stay or residence in the city, the BIKEKIA 'bike-sharing' system is rated as the best project in all groups of respondents (with the exception of commuters), while commuters consider a project promoting electronic communication between citizens and the office to be the best project. Respondents studying in Žilina showed indifference towards an intelligent system for regulating pedestrian entrances and a modern contact point for services for citizens. According to the questionnaire, only respondents with permanent residence in the city consider the regulation of access to the pedestrian zone to be the best project; other groups did not vote for the said project at all. In addition, respondents staying temporarily in the city did not rate the project related to air quality monitoring as the best project.

When determining the significance of individual areas of the smart city concept, it was possible to state more answers and mark their order. What is essential within the concept of smart city for citizens? Multiple answers were possible to the results of the survey in terms of the importance of the smart city concept. Respondents identified mobility as the most important part of the concept $(24 \%)$. In second place there was the environment $(20 \%)$ and in third place the city administration (18\%). On the other hand, less than 5 per cent of respondents chose the field of sports and culture in terms of importance within the Smart City Žilina concept (Table 2).

\begin{tabular}{|c|c|c|c|c|}
\hline \multicolumn{5}{|l|}{ Permanent residence } \\
\hline \multicolumn{5}{|l|}{ Temporary residence } \\
\hline \multicolumn{5}{|l|}{ School attendance } \\
\hline \multicolumn{5}{|l|}{ Attendance at work } \\
\hline \multirow[t]{2}{*}{0} & $20 \%$ & $40 \%$ & $60 \%$ & $80 \%$ \\
\hline & Attendance at work & School attendance & Temporary residence & Permanent residence \\
\hline Bikesharing system BIKEKIA & 1 & 7 & 4 & 33 \\
\hline $\begin{array}{l}\text { E-communnication of the } \\
\text { citizen with the city }\end{array}$ & 6 & 3 & 3 & 13 \\
\hline $\begin{array}{l}\text { Smart system for controlling the } \\
\text { entrance to the pedestrian zone }\end{array}$ & 0 & 0 & 0 & 7 \\
\hline $\begin{array}{l}\text { Modern contact workplace for services } \\
\text { for citizens }\end{array}$ & 3 & 0 & 3 & 8 \\
\hline Air quality monitoring & 3 & 3 & 0 & 6 \\
\hline Smart Public Transport & 3 & 3 & 2 & 7 \\
\hline
\end{tabular}

Fig. 4. The best project within the Smart City concept in Žilina depending on the respondent's stay in the city. Source: Halamova, E. 2020. 


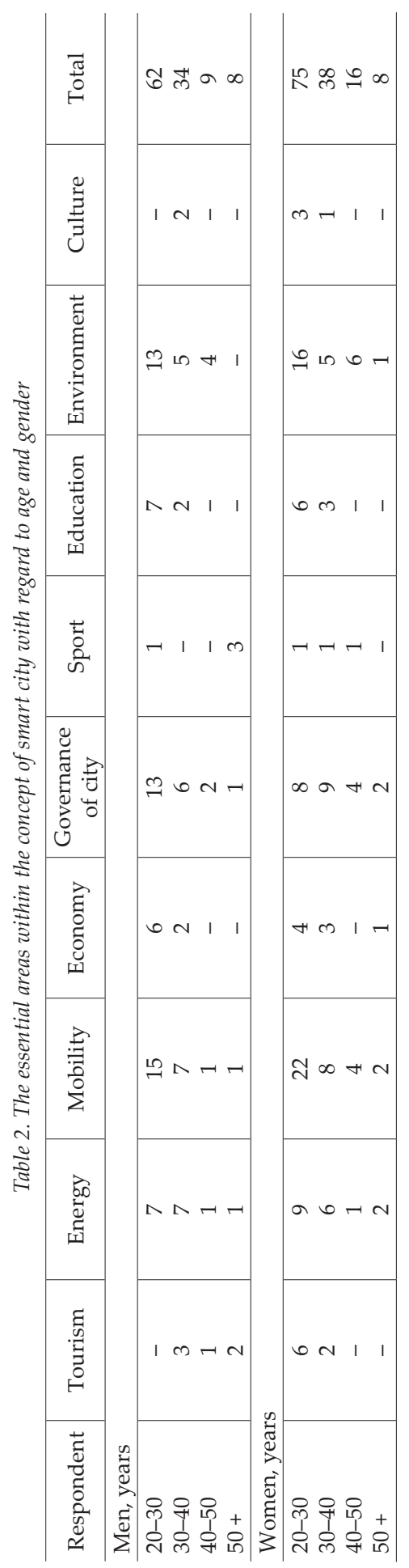

\section{Discussion and conclusion}

Based on the primary and secondary research results, we focused on identifying opportunities for the development of the smart city Žilina concept. For the citizens of Žilina, as well as for students and employees, there is a growing interest in:

- Smart means of communication with the municipality;

- Waste management;

- Renewable resources;

- Green solutions. For example, a significant number of respondents consider support for green roofs to be a key area.

These are topics perceived by citizens as important. From the point of view of a smart city, the open communication of the municipality with all stakeholders, citizens and visitors can be fulfilled through the adoption of other solutions in the field of the environment. In this area, Žilina is ranked, based on the smart city index (see Table 1), in sixth place out of eight ranked places. Clearly, the challenge of creating a sustainable environment is also reflected in public perceptions of the importance of this area to the city.

Cities have yet to become aware of the urgency of these challenges and the need to implement the laws of Slovakia. Introduced in 2021, the legislation also covers the separate collection of waste in colour-coded containers.

The updating of the strategy must consider a number of steps in waste management, including separation and collection, with a view to the overall recovery of the waste generated. Further steps must be aimed not only at reducing waste costs, but also at improving the services provided to citizens from an environmental point of view. Although these solutions will require an initial investment, they will ultimately lead to improved services.

In our opinion, the feasibility of these goals in smart environmental policy may be achieved by 2030. Services in a real smart city should communicate with each other and make use of both their own technological data and municipal data (such as the databases of municipal authorities, transport 
companies, water companies, schools and other municipal institutions). They should also draw on other data sources, such as public data from reference registers. A unified database would make it possible to build a wider portfolio of services at lower cost, as the interconnection of data sources is solved together for all services.

In connection with the development of a smart city, public administration institutions must focus their attention on:

- Connecting the target groups.

- Satisfied citizens, customers and transport users.

- Relations with workers, public service employees.

- Relations with the government, public sector, business sector, including lobbying.

- Relations with the media, the general public, 'belonging to ...', relations, membership, etc.

The following aspects should be especially highlighted:

- Public perceptions of individual measures. A positive perception of measures among the public has a decisive influence on the use of smart city technologies and services, as well as on the effectiveness of individual measures to ensure sustainability and, where appropriate, increase performance. It is necessary to work consistently with the public and influence its attitudes towards new solutions by explaining the benefits, etc.

- The impact on the sustainability of technical solutions. The application of smart city technologies and services is connected with the provision of routine operation and innovation of lower-order services, which require a thorough focus on the organizational provision of deployed innovative services.

- Systems and measures to ensure the quality of life in the city.

The impacts of the implementation of smart city projects must be assessed in terms of their life cycle (i.e. the impacts or effects of projects in the planning, evaluation and design phases, political decisions, construction or implementation and operation). For each impact, appropriate indicators must be used, and their interrelationships established. Changes in the city associated with the implementation of smart solutions can have a positive or negative impact on other parts of the region or locality. It can be assumed that positive impacts in one place will cause negative impacts in another place in the region - cities - localities. Therefore, there is a need to assess how the competitiveness of the urban part - localities - cities - regions changes (growth - decrease) in comparison with other localities - cities - regions and to compare the development in relation to the development in the whole state, in the national economy.

Communication within the smart city is quite specific and also requires specific approaches and tactical decisions for optimal success. Access to project information within the smart city needs to be coupled with an outline of the content and purpose of the project, explaining how the proposed solution replaces and complements existing solutions as perceived by the public. Positive perceptions crucially affect the use of technologies and smart city services as well as the effectiveness of various measures to ensure sustainability solutions. Proper marketing communication means to interpret the messages that describe the already existing solutions or should include research results without ties to the specific products or time data.

When addressing the issue of a smart city, partnerships are established by law with the aim of generating multiple benefits. Partnerships are essential in this area, but it should be borne in mind that they will have a major impact on marketing communications and public relations activities. If the partners agree, each communication activity gains added value and meaning. However, partners do not always have to share the same views and may have hidden intentions. Another problem may be the leakage of information, which can be prevented by the greatest possible degree of harmonization of partnership cooperation. The effectiveness 
of applying the right approach and tactics depends on eliminating weaknesses in the partnership agreements and creating a solid foundation for the partnership.

When communicating with the public about smart solutions and the whole concept of a smart city, it must not be forgotten to whom the communication activities are aimed. The so-called target groups and communication tools are in the centre of attention. All messages communicated in the field of smart city must be attractive and comprehensible to the target groups and must correspond to their interests. A great or significant opportunity for the city of Žilina is the cooperation with the university and other research institutions, as well as non-governmental organizations focused on the development of non-motorized transport in particular in the field of smart mobility.

The transformation of the city into a smart city requires, above all, a systemic approach, which must be based not only on the vision and mission of the settlement unit but also on a common database when using e-services. However, in order to ensure the interoperability of e-services, the local government should, in accordance with the draft framework of e-services, rely on requirements developed both in Slovakia and at the level of the European Union. It is necessary to transfer the smart city strategy not only to the main strategic plan of the city, but also to the strategic plans of individual areas. Our findings on public perceptions of smart solutions are also a starting point and an opportunity for formulating strategic goals and tactical approaches of the municipality within the context of EU cohesion policy for the years 2021-2027. Smart solutions are not used to compete with other cities and to gain a certain position in terms of rankings. However, they provide inspiration for other locations and provide valuable information for the city management itself about the adoption of smart solutions or policies by citizens.

Support for smart cities and regions should be based on the cooperation of all stakeholders from the very beginning of the process, starting with the formulation of a vision, priorities and policy options and leading to the definition of specific measures. First and foremost, it is essential to inform and motivate all stakeholder groups, with a view to facilitating joint efforts aimed at developing a concept or strategy of effective cooperation. Civil society needs to be involved in the process, as active citizens can initiate changes that will support smart city projects. The more citizens are involved in the city's development process, the better the city will serve the needs of its inhabitants. City authorities must be a driving force enabling Smart City-related activities. Without such leadership, it would be almost impossible to transform 'ordinary' cities in Slovakia into smart cities. Cities, as public and transparent players, are becoming natural open and innovative platforms. It is important that they perceive and support emerging innovative ecosystems.

Acknowledgements: The authors would like to express their appreciation and gratitude to the anonymous reviewers for their remarks and suggestions aimed at broadening the research topic. This contribution was undertaken as a part of the research project VEGA 1/0011/21 Research on the interactions among new emerging technologies, the performance of enterprises and industries based on network technology infrastructure, the application of new business models and the institutional regulatory, environmental, and social environment.

\section{REFERENCES}

Cohen, B. 2012. What exactly is a smart city? Fast Company 19. September, 2012. Available at https:// www.fastcompany.com/1680538/what-exactly-isa-smart-city

Cohen, B. 2014. The smartest cities in the world 2015: Methodology Fast Company 20 November, 2014. Available at https://www.fastcompany. com/3038818/the-smartest-cities-in-the-world2015-methodology

Czirják, R. 2016. Okos városokkal a globális társadalmi kihívások kezeléséért? (With smart cities for the treatment of global social challenges?) Budapest, 
PAGEO Geopolitical Research Institute. Available at http://www.geopolitika.hu/hu/2016/09/23/ okosvarosokkal-a-globalis-kihivasok-kezeleseert/

DADO, M., Zahradník, J. et al. 2007. Technológie a služby inteligentnej dopravy (Intelligent transport technologies and services). Žilina, Žilinská univerzita v Žiline/EDIS - vyd. ŽU.

DÁvid, L. and Szúcs, Cs. 2009. Building of networking, clusters and regions for tourism in the Carpathian Basin via information and communication technologies. Hungarian Information Society 23. 1-2. 63-74. Available at https://doi.org/10.4000/netcom.849; https://journals.openedition.org/netcom/849

Department Business, 2013. Smart cities - background paper. London, UK Government, Department for Business, Innovation and Skills. Available at https://assets.publishing.service.gov.uk/government/uploads/system/uploads/attachment_data/ file/246019/bis-13-1209-smart-cities-backgroundpaper-digital.pdf

Dobos, K., Kulcsár, S., Nagy, P., Sik, A., Szemerey, S. and Vasváriné Dr. MenYhárt, É. 2015. Smart City Tudásplatform (Metodikai Javaslat) (Smart City Knowledge Platform [Methodological Proposal]). Budapest, Lechner Nonprofit Ltd. Available at http://lechnerkozpont.hu/doc/okos-varos/ smart-city-tudasplatform-metodikai-javaslat.pdf

Egedy, T. 2017. Városfejlesztési paradigmák az új évezredben - A kreatív város és az okos város (Urban development paradigms in the new millennium - The creative city and the smart city). Földrajzi Közlemények 141. (3): 254-262. Available at: https://www.foldrajzitarsasag.hu/downloads/foldrajzi_kozlemenyek_2017_141_evf_3_pp_254.pdf

Erdeiné Késmárki-Gally, Sz., FenYvesi, L. and TAKÁCs-GYÖRGY, K. 2015. The role of agricultural e-market place in public organizations. Optimum. Studia Ekonomiczne 6. (78): 15-26. Doi: 10.15290/ ose.2015.06.78.02

European Smart Cities 3.0 Home. Copyright $(C$ 2013-2021 Dan.com an Undeveloped BV subsidiary. Available at http://www.smartcities.eu/?cid=1\&ver=3

Europeansmartcities TU Vienna. 2017. Available at http://www.smart-cities.eu/

Giffinger, R. and Haindlmaier, G. 2010. Smart cities ranking: An effective instrument for the positioning of the cities. ACE: Architecture, City and Environment 4. 1-11.

Hal'amova, E. 2020. Návrh stratégie implementácie nozých $e$-služieb v sídelnom útvare Žilina (Proposal of a strategy for the implementation of new e-services in the Żilina unit). Diploma thesis. N. 28330420202013. Žilina, Žilinská univerzita v Žiline.

Jesenko, M. 2017. Právo obce na samosprávu a normotvorba obcí (The right of a municipality to self-government and the norm-setting of municipalities). Košice, Univerzita Pavla Jozefa Šafárika v Košiciach.
JiA, Q. and $\mathrm{XU}_{\mathrm{U}}$ C. 2021. Smart city image landscape design based on wireless sensors. Microprocessors and Microsystems 83. 104022

Kalašová, A. 2012. Inteligentné dopravné systémy základ trvalo udržatel'ného rozvoja. (Intelligent transport systems - the basis of sustainable development). Svet dopravy 0/2012 Bratislava, ASATECH.

Kiss, É. and NedeLKa, E. 2020. Geographical approach of Industry 4.0 based on information and communication technologies at Hungarian enterprises in connection with industrial space Hungarian Geographical Bulletin 69. (2): 99-117. Doi: 10.15201/ hungeobull.69.2.2; https://ojs.mtak.hu/index.php/ hungeobull/article/view/3191/2815

Liquid State: Smart Cities, Smart Citizens, Smart Apps. 2017. Available at https://liquid-state.com/smartcities-smart-citizens-smart-apps/

Madudova, E. and Dávid, A. 2019. Identifying the derived utility function of transport services: case study of rail and sea container transport. Transportation Research Procedia 40. 1096-1102.

MatúšKová, M. and MadleñÁKovÁ, L. 2016. The impact of the electronic services to the universal postal services. Procedia Engineering 178. 258-266.

MCQuiRe, S. 2021. Urban digital infrastructure. Smart cityism and communication: Research challenges for urban e-planning. International Journal of E-Planning Research 10. (3): 1-10.

Meijer, A. and Rodríguez Bolívar, M.P. 2015. Governing the smart city: a review of the literature on smart urban governance. International Review of Administrative Sciences 82. (2): 392-408. Available at https://doi.org/10.1177/0020852314564308

Mossberger, K. and Tolbert, C.J. 2021. Digital citizenship and digital communities: How technology matters for individuals and communities. International Journal of E-Planning Research 10. (3): 19-34.

New Cohesion Policy 2018. Available on https://ec.europa.eu/regional_policy/en/2021_2027/

Rechnitzer, J., Berkes, J. and Filep, B. 2019. The most important city development initiatives of Hungary. Regional Statistics 9. (2): 20-44.

SAD Žilina, 2019. Online služby SAD Žilina vám ul'ahčia cestovanie autobusom (SAD Žilina online services will make travelling by bus easier). Available at https:// www.sadza.sk/aktualita/614-online-sluzby-sad-zilina-vam-ulahcia-cestovanie-autobusom/

Smart cities definition. Available at http://www. smart-cities.eu/

Smart City-Definition 2021. BusinessDictionary.com Smart City. Definition of Smart Cities. Available at https://www.smartcity.gov.sk/definicia-smart-cities/index.html

ŠILHAN, Z. and KUNC, J. 2020. Two decades of changes in spatial distribution of retail and commercial services: Czech experience Hungarian Geographical Bulletin 69. (1): 41-55. 
Soe, R.M. 2017. FINEST Twins: platform for cross-border smart city solutions. In Proceedings of the $18^{\text {th }}$ Annual International Conference on Digital Government Research, June 2017.352-357. Available at https://doi.org/10.1145/3085228.3085287

Strelcová, I. 2016. Nové elektronické služby pre zákazníkov SAD Žilina (New electronic services for SAD Žilina customers). Available at http:// www.busportal.sk/modules.php?name=article\&sid=10749

TóтH, G., DÁvID, L. and VAsA, L. 2013. Transportation and accessibility at European level. Regional Statistics 3. (1): 79-97.

Turská, S. and Madlenáková, L. 2019. Concept of smart postal mailbox. Transportation Research Procedia 40. 1199-1207.

VAculík, J. and Tengler, J. 2012. Potential of new technologies in logistics services. In Congress Proceedings, CLC - Carpathian Logistics Congress, 7-9. 11. 2012, Jeseník, CZ. 242-250.
Woetzel, J., Remes, J., Boland, B.L.K., Sinha, S. Strube, G. and von der TAnN, V. 2018. Smart Cities: Digital Solutions for a More Liveable Future. San Francisco, McKinsey Global Institute. Available at http://www.Mckinsey.com

ZimánYi, K., KoZÁr, L. and Kôvári, I. 2014. A new form of on-line sales in commerce and tourism: Trends, advantages and risks. Journal of American Business Review 2. (2): 104-109.

ŽSK 2015. ŽSK Portal. Available at https://online. zilinskazupa.sk/

ŽSK 2016. Elektronizácia služieb v Žilinskom samosprávnom kraji (Electronic services in the Žilina self-governing region). Available at <http://www. zilinskazupa.sk/sk/info-zurnal-zsk/aktualitky-z-odborov-uradu-zsk/aktuality-z-uradu-zsk/ elektronizacia-sluzieb-zilinskom-samospravnom-kraji.html> 